\title{
Assessment of Microbial Quality of Vegetables Irrigated with Polluted Waters in Dar es Salaam City, Tanzania
}

\author{
Mary C. Kayombo, Aloyce W. Mayo* \\ Department of Water Resources Engineering, University of Dar es Salaam, Tanzania
}

Copyright $\mathrm{C} 2018$ by authors, all rights reserved. Authors agree that this article remains permanently open access under the terms of the Creative Commons Attribution License 4.0 International License

\begin{abstract}
This study was undertaken to assess microbial quality of fresh vegetables irrigated with polluted waters from Msimbazi River in Dar es Salaam City. Samples of river water were taken from seven sampling stations along Msimbazi River stretching $20.4 \mathrm{~km}$ from Pugu to Jangwani and its tributary (Ubungo River) at Mabibo. Vegetable samples of 5 different species were taken from two different vegetable gardens in different locations along Msimbazi river valley and its tributary (Ubungo river), and from six markets including one super market. The examination of samples was carried out in accordance with the standard methods. Results revealed that water from the Msimbazi River contains high concentration of salts and pathogenic organisms. Fecal coliforms were found in all river water samples with a maximum count of $2.1 \times 10^{6}$ $\mathrm{cfu} / 100 \mathrm{ml}$. Pollution of the river was increasing downstream and varies seasonally with wet season having poorer water quality than dry season. Vegetables from all the markets including super market were highly contaminated with fecal coliforms of up to $10^{8} \mathrm{Cfu} / \mathrm{kg}$-wet vegetables. Pathogenic organisms were detected on vegetables and all river water samples examined had Ascaris Lumbricoides except for the sample collected at Pugu station. Fresh vegetables were contaminated with pathogenic organisms such as Escherichia coli, Citrobacter ssp, Proteus ssp, Klebsiella ssp, Salmonella spp and Basillus spp. Vegetable samples collected from the markets were more contaminated than those collected from the gardens. High number of fecal coliforms in the markets was due to poor handling of these vegetable by contaminated hands and sprinkling of vegetables with polluted water to keep vegetables moist. It was concluded that water used for irrigating vegetables along river Msimbazi was highly polluted and vegetables from gardens and markets are not safe for consumption.
\end{abstract}

Keywords Faecal Pollution, Microbial Quality, Vegetables, Msimbazi River

\section{Introduction}

Worldwide, agriculture is under a strong pressure to produce more food for the ever increasing population $[1,2]$. The rapid rate of urbanization in developing countries has led to serious concerns on household food security and also increased demand for water supply for both drinking and agricultural activities [3, 4]. Urban agriculture including vegetable farming, offers an important role in the economic, social, and dietary life of many urbanites with a vital economic role of acting as a source of income for producers and distributors [2]. Fruits and vegetables in particular are important sources of essential trace elements for communities especially in developing countries as they can be consumed at a relatively low price [5].

Owing to rapid population growth associated with urban development in relation to increased socio-economic activities, and environmental challenges like climate change, pollution and land degradation has reduced the availability and quality of water sources [1]. As a result of water scarcity, there is high potential of using untreated wastewater as well as exploiting undeveloped water sources $[6,7]$. Since urbanization leads to an increase in wastewater production, wastewater has become a potential source of water for agricultural activities [8]. Because the use of potable water for irrigation is very expensive [9], the alternative option remains the use of surface water from polluted rivers [10], which poses potential human health risks due to the presence of pathogenic organisms from infected livestock or human hosts $[4,7]$. As a result, there is a potential risk for the health of consumers of crops irrigated with contaminated water, especially fresh vegetables, which may at times be consumed without cooking when eaten as salad [11].

Several studies have shown that raw vegetables may harbor potential food-borne pathogens [11, 12]. In particular, tomatoes, cantaloupes, and sprouts have been linked to outbreaks of salmonellosis [13]. Some scholars have also reported outbreak of illnesses caused by Escherichia coli O157:H7, which is associated with lettuce, 
and radish sprouts [14]. In other studies coleslaw, cabbage, potatoes, radishes, bean sprouts, and cucumbers contaminated with Listeria monocytogenes have been linked to disease outbreaks and salad vegetables also may be contaminated with Campylobacter $[15,16]$. Examples of disease outbreaks linked with consumption of raw vegetables include E. coli O157: H7 in Montana and Connecticut in U.S.A and S. Sonnei in Sweden and other European countries, Hepatitis A infections in Kentucky in U.S.A. and Sweden, which were associated with the consumption of lettuce or green salad. In accordance with Raicevic et al. [11], Salmonella infection in 1990, 1993 and 1999 in United States was due to consumption of tomatoes, and Salmonella spp., E. coli 0157: H7, B. cereus, L. Monocytogenes, $Y$. Enterocolitica, and Shigella spp in Japan were associated with radish sprouts that affected 10,000 people.

In Tanzania, urban agriculture is characterized by unsafe practices and high risk of chemical pollution and contamination of pathogens, which puts the farmers and crop users at a very high rate of infections [17]. Most of vegetables cultivated for commercial purposes are grown near polluted water bodies particularly along the rivers because river water is cheap and reliable. However, rivers flowing through towns and cities in Tanzania such as Karanga, Njoro and Rau in Moshi; Mirongo in Mwanza and Themi in Arusha, are known to be highly polluted [4].

The demand for vegetables is high in major cities and towns in Tanzania, particularly in Dar es Salaam with over 4.3 million people. To meet such high demands of vegetables, many farmers use polluted surface water from rivers within the city for irrigation of vegetables because of inadequate clean water supplies [4, 7]. Unfortunately, river waters are polluted by informal settlements located near these rivers systems, which lack adequate sanitation and are therefore prone to microbial contamination $[8,18]$. For instance, in Dar es Salaam city, most of the vegetables are grown along rivers like Msimbazi, Mlalakua, Tegeta and Kizinga, which are recipients of wastewater from industries, commercial areas and residential areas [7, 19]. Therefore fresh vegetables grown in these areas have the potential of being contaminated with human pathogens due to the use of untreated wastewater for irrigation. This represents an important route for transmission of pathogenic organisms [20] into the soil once water is used for irrigation [21]. The study aimed at assessing the microbial contamination of fresh vegetables along River Msimbazi and its tributaries.

\section{Materials and Methods}

\section{Description of Study Area and Sampling Sites}

Dar es Salaam city, which covers an area of about 1,393 $\mathrm{km}^{2}$, is located between latitude $6^{\circ} 20^{\prime} \mathrm{S}$ to $7^{\circ} 30^{\prime} \mathrm{S}$, and longitude $39^{\circ} 00^{\prime} \mathrm{E}$ to $39^{\circ} 30^{\prime} \mathrm{E}$ [22]. The city has population of 4,364,541 and annual growth rate of $5.6 \%$, which is the highest rate of growth in the country in accordance with 2012 Population and Housing CensusPHC [23]. About $70 \%$ of the city's population live in unplanned settlements, which are characterized by lack of basic urban infrastructure services including water supply system, proper sanitation facilities, access roads, drainage and proper waste management systems. Samples were collected from six stations along Msimbazi River at Pugu at Banguro bridge (Station S1), Gongo la Mboto at Ulongoni bridge (Station S2), Vingunguti bridge (Station S3), Tabata Matumbi at Mandela Expressway bridge (Station S4), Kigogo Sambusa at Kawawa road culvert (Station S5) and Morogoro road at Jangwani bridge (Station S6) and Ubungo river at Bonde la Mchicha (Station S7). The surroundings of the sampling stations have different characteristics ranging from high density residential areas, to low density communities (Table 1). Some of the stations are surrounded by industries, farm lands, garages, waste stabilization ponds and abattoir. 


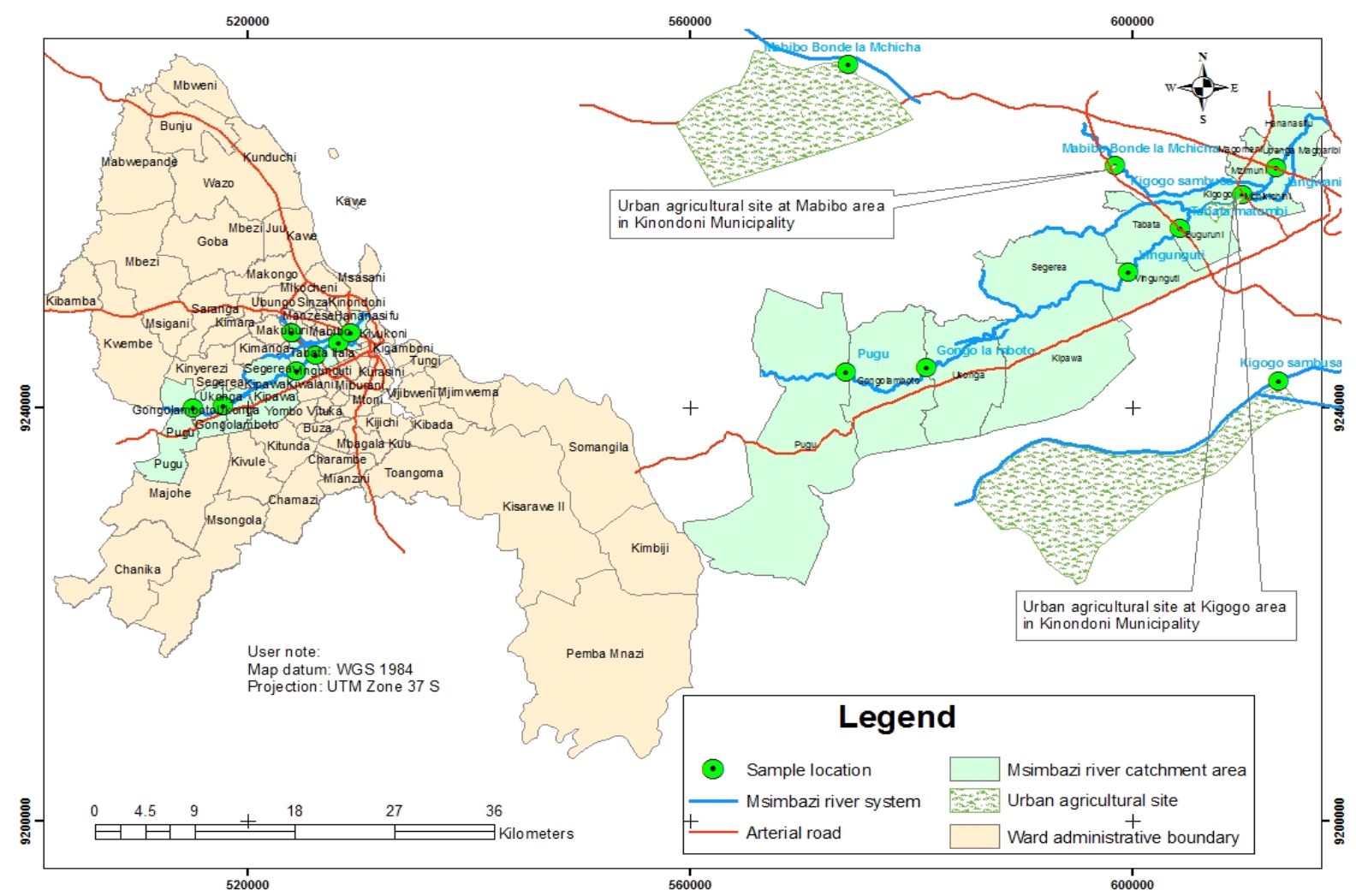

Figure 1. Map of Dar es Salaam showing the location of sampling station

Table 1. Sampling stations with coordinates

\begin{tabular}{|c|c|c|c|c|c|}
\hline \multirow{2}{*}{ Location } & \multirow{2}{*}{$\begin{array}{l}\text { River/ } \\
\text { Station }\end{array}$} & \multirow{2}{*}{ Code } & \multicolumn{2}{|c|}{ GPS Coordinates } & \multirow{2}{*}{ Activity/ Establishment } \\
\hline & & & Northing & Easting & \\
\hline Pugu at Banguro Bridge & Msimbazi Main & S1 (River) & 0515133 & 9240055 & Residential area (low density) \\
\hline $\begin{array}{l}\text { Gongo la Mboto at Ulongoni } \\
\text { Bridge }\end{array}$ & Msimbazi Main & S2 (River) & 0517801 & 9240189 & Residential area \\
\hline Vingunguti Bridge & Msimbazi Main & S3 (River) & 0524454 & 9243573 & $\begin{array}{l}\text { High density residential area, } \\
\text { Wastewater ponds, Industries }\end{array}$ \\
\hline $\begin{array}{c}\text { Tabata Matumbi at Mandela } \\
\text { Bridge }\end{array}$ & Msimbazi Main & S4 (River) & 0526166 & 9245117 & Residential, Industrial area \\
\hline \multirow{2}{*}{$\begin{array}{l}\text { Kigogo Sambusa at Kawawa } \\
\text { road Culvert }\end{array}$} & \multirow{2}{*}{ Msimbazi Main } & S5 (River) & 0528256 & 9246285 & \multirow{2}{*}{ Residential area } \\
\hline & & Farm & 0528230 & 9246252 & \\
\hline $\begin{array}{c}\text { Morogoro road at Jangwani } \\
\text { Bridge }\end{array}$ & Msimbazi Main & S6 (River) & 0529345 & 9247274 & $\begin{array}{c}\text { Residential area } \\
\text { (high density) }\end{array}$ \\
\hline \multirow{2}{*}{ Mabibo at Bonde la Mchicha } & \multirow{2}{*}{ Tributary } & River (R3) & 0523990 & 9247339 & \multirow{2}{*}{$\begin{array}{c}\text { Residential area, } \\
\text { Garage, Petrol station }\end{array}$} \\
\hline & & Farm (F3) & 0524019 & 9247344 & \\
\hline
\end{tabular}

\section{Sampling Procedures and Preparation of Samples}

Fresh vegetable samples were collected once a week for four months from the selected stations along the river during dry and wet seasons (Fig. 1). Samples were collected from Kigogo Sambusa farm (Vf1), Mabibo Bonde la Mchicha farm (Vf2) Kigogo Market (Vm1), Mabibo Market (Vm2), Buguruni Market (Vm3), Kariakoo Market (Vm4) Mwenge Market (Vm5) and from one large super market at Mlimani city. Water samples were collected using $250 \mathrm{ml}$ sterilized glass bottles. Sample was collected from 7 stations (Table 1) using sampling techniques and protocols in accordance with the Standards methods for the examination of water and wastewater samples [24]. Samples were stored in cool boxes during transportation and were tested immediately upon arrival (within $4 \mathrm{hrs}$ ). Samples were prepared in accordance with the standard procedures and incubated for $24 \mathrm{hrs}$ for fecal coliform. Water samples were analyzed for microbial parameters, which includes fecal coliforms and nematodes including Dracunculus medinesis, Enterobius vermicularis, Ascaris lumbricoides and Trichuris trichiura. 
Samples of fresh vegetables of African Spinach leaves (Amaranthus spp), Pumpkin leaves (Curcubita moschata), Sweat potato leaves (Ipomea batata), Chinese cabbage leaves (Brassica chinensis) and Kale leaves (Brassica oleracea) were collected; just before harvesting, fresh from the farm and from markets where they were picked randomly from the vendors. Vegetable samples were put in labeled sterile polythene bags, and transported in a cool box to the laboratory where they were analyzed immediately. Vegetable samples were examined for fecal coliforms and helminthes eggs including Dracunculus medinesis, Enterobius vermicularis, Ascaris lumbricoides and Trichuris trichiura. Vegetables were also examined for the presence of Escherichia coli, Citrobacter spp, Proteus spp, Krebsiella spp, Salmonella spp, and Bacillus spp.

\section{Examination of Water Samples}

- Procedure for pour plate count for fecal coliform in irrigation water

Water samples were analyzed quantitatively for fecal coliform using standard plate count method in accordance with the Standard methods for the examination of water and wastewater samples [24]. Sterilized MF/C agar base for fecal coliforms was melted in a hot plate by immersing the $125 \mathrm{ml}$ Erlenmeyer flask in the autoclave operated at $121^{\circ} \mathrm{C}$ for 15 minutes. The agar was then allowed to cool to about $45^{\circ} \mathrm{C}$ and held in a water-bath at temperature of $43^{\circ} \mathrm{C}-45^{\circ} \mathrm{C}$. Then water sample was shaken vigorously and $1 \mathrm{ml}$ of well shaken sample was aseptically transferred with a sterile pipette to a sterile Petri dish. About $10 \mathrm{ml}$ of melted agar medium cooled to about $43^{\circ} \mathrm{C}$ was then poured and mixed by rotating and tilting Petri dishes. The medium was then allowed to harden and Petri dish contents were incubated for 24 hours at $45^{\circ} \mathrm{C}$, after which colonies of bacteria were counted using an illuminated colony counter.

- Procedure for Helminthes eggs examination in irrigation water

About $200 \mathrm{ml}$ of wastewater sample was collected and allowed to sediment in a beaker for 2 hours. About $90 \%$ of the supernatant was then removed using syringe and sediments were transferred to two centrifuge tubes of $10 \mathrm{ml}$ capacity each and centrifuged at $3000 \mathrm{rpm}$ for 15 minutes. The supernatant thereafter was removed and all sediments transferred to one tube and centrifuged at $1000 \mathrm{~g}$ for 15 minutes. The pellet was then transferred in an equal volume of acetoacetic buffer to make a total volume of $4 \mathrm{ml}$ and an equivalent volume of ethyl acetate was then added and mixed using vortex equipment. The solution was then centrifuged at $1000 \mathrm{~g}$ for $15 \mathrm{~min}$ where three distinct layers were observed, the bottom layer contained non fatty material and the eggs, the middle layer contained the buffer and top layer contained fatty and other materials which formed a thick duck plug. The volume of the bottom most layer, which contains helminthes eggs, was recorded and the rest of the supernatant layers were poured off. The pellet was then re-suspended into five volumes of zinc sulphate solution, and the solution mixed by vortex. An aliquot of $1.5 \mathrm{ml}$ was then transferred to McMaster slide and left for 5 min before examination; two slides one at a time was thereafter placed and viewed from the microscope at $10 \mathrm{xs}$ for eggs count. Shapes of eggs as viewed from the microscope were compared to Plates I-XVII in the Ayres and Mara [25] that show a number of eggs of the human parasitic helminthes most frequently encountered in wastewater and other source samples to identify the type of helminthes available.

\section{Microbial Examination of Pathogens of Vegetables}

(a) Procedure for plate count for fecal coliform in vegetables

Approximately $20 \mathrm{~g}$ of vegetables was weighed and soaked into $180 \mathrm{ml}$ sterilized buffered Peptone Water with $\mathrm{NaCl}$ for 5 to 10 minutes, which is recommended as a diluents for carrying microbial tests. The liquid content was then shaken vigorously before sample was extracted and diluted with appropriate sterilized dilution water before determination of fecal coliform density. The examination of fecal coliforms was carried out using pour plate technique in accordance with the Standard methods for the examination of water and wastewater samples [24].

\section{(b) Procedure for determination of bacteria organisms in vegetables}

About $1 \mathrm{~g}$ of the sample was immersed into $5 \mathrm{ml}$ of nutrient broth and left for 30 minutes. The diluents was then inoculated on Blood Agar (BA) and MacConkey Agar by using a wire loop, which was then streak on the Petri dish and incubated at $37^{\circ} \mathrm{C}$ for 24 hours. The identification of bacterial colonies was done by Macro morphology method, which was later followed by microscopic observation of different bacterial cells (micro morphology) using Grams stain technique to determine whether bacteria are Gram-Negative or Gram-Positive. Further tests such as Triple Sugar Iron (TSI) and Indole, Methyl red, Voges Proskeur and Citrate (IMVIC) were done for confirmation of the type of organisms.

\section{(c) Procedure for determination of Helminthes eggs in vegetables}

Vegetable samples were immersed immediately in sterilized water inside a sterile container and left for approximately 6-7 minutes in order to allow mud and other solids to settle in the bottom of the container. Then, it was gently collected and was put in a plastic basket. Each vegetable sample was eluted by vigorous agitation for $30 \mathrm{~min}$ and allowed to sediment in a beaker for two hours, ninety percent of the supernatant was removed using siphonic action (syringe) and sediments were transferred to two centrifuge tubes of $10 \mathrm{ml}$ capacity each and 
centrifuged at $1000 \mathrm{~g}(3000 \mathrm{rpm})$ in 15 minutes. The supernatant was then removed and all sediments were transferred to one tube and centrifuged at $1000 \mathrm{~g}$ for 15 minutes. The pellet was then transferred in an equal volume of acetoacetic buffer to make a total volume of $4 \mathrm{ml}$, which was followed by the addition of $4 \mathrm{~mL}$ of ethyl acetate. The contents were then mixed using vortex equipment and the solution was thereafter centrifuged at $1000 \mathrm{~g}$ for 15 minutes.

\section{Statistical Analysis}

Statistical analysis was done using excel window 2007 and GIS-ArcMap Version 9.2. Graphs and Charts were generated to establish characteristics of water quality and vegetables at different selected sampling stations. Spearman's Correlation (rs) analysis was applied to quantitatively analyze and confirm the relationship among the water quality characteristics of selected rivers and the microbial quality of irrigated vegetables.

\section{Results and Discussions}

\section{Assessment of the Microbial Characteristic of Irrigation Water}

Table 2 shows the results of the microbial quality of irrigation water from different sites along Msimbazi River. The results indicate that Ascaris lumbricoides eggs were detected in all sites except at the most upstream sampling station (station 1 -Pugu at Banguro Bridge). All other nematodes (Dracunculus medinesis, Enterobius vermicularis and Trichuris trichiura) were not detected in the river water. The presence of Ascaris lumbricoides eggs in the river, which is the most common intestinal parasite affecting human beings [26, 27], might be due to its prevalence worldwide particularly in tropical areas [27] and their ability to resist various external environmental conditions including chemicals [1]. They have direct life cycle and their ova are found in raw or insufficiently treated sewage, fertilizer and soil that may simply contaminate water bodies especially when erosion occurs. Also they may contaminate crops grown in soil or fertilizes that has receives non-lethal treatment [28, 29].

The examination of fecal coliforms shows that there was a difference in the fecal coliform counts of water between the sites in the study area (Fig. 2). Station 1 (Pugu at Banguro Bridge), Station 3 (Vingunguti), Station 4 (Tabata Matumbi) and Site 5 (Kigogo Sambusa) had higher fecal coliform counts than Station 2 (Gongo la Mboto) and Station 6 (Jangwani). Higher level of coliform counts at Pugu might be due to non point source of pollution including open defecation, which is later taken by water into the river. The variation of coliform counts at Vingunguti, Tabata Matumbi and Kigogo Sambusa is influenced by the coliform dynamics in the stream and the bacteriological quality of point's sources, which contribute to the pollution to the sites. However, levels of fecal coliform counts observed were greater than $1,000 \mathrm{cfu} / 100$ $\mathrm{ml}$ in all the sampling sites, suggesting that none of the water samples from the sites met the guideline limit for fecal coliform bacteria in unrestricted irrigation of crops likely to be eaten raw in accordance with international standards [28]. Thus water from the river is unsuitable for human consumption and for irrigation of vegetables and salad crops without prior treatment [30].

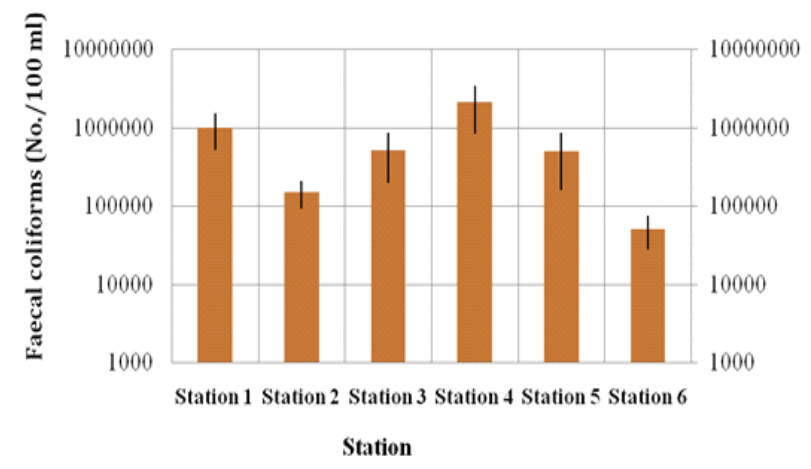

Figure 2. Fecal coliform counts of irrigation water along Msimbazi River

Table 2. Microbial characteristic of irrigation water from the river

\begin{tabular}{|c|c|c|c|c|c|c|}
\hline \multirow{2}{*}{\begin{tabular}{c} 
Parameter \\
\cline { 2 - 7 }
\end{tabular}} & $\mathrm{S} 1$ & $\mathrm{~S} 2$ & $\mathrm{~S} 3$ & $\mathrm{~S} 4$ & $\mathrm{~S} 5$ & $\mathrm{~S} 6$ \\
\cline { 2 - 7 } Fecal coliform (No/100ml) & $1.0 \times 10^{6}$ & $1.5 \times 10^{5}$ & $5.2 \times 10^{5}$ & $2.1 \times 10^{6}$ & $5.0 \times 10^{5}$ & $5.0 \times 10^{4}$ \\
\hline Ascaris lumbricoides & Not Detected & Detected & Detected & Detected & Detected & Detected \\
\hline Dracunculus medinesis & Not Detected & Not Detected & Not Detected & Not Detected & Not Detected & Not Detected \\
\hline Enterobius vermicularis & Not Detected & Not Detected & Not Detected & Not Detected & Not Detected & Not Detected \\
\hline Trichuris trichiura & Not Detected & Not Detected & Not Detected & Not Detected & Not Detected & Not Detected \\
\hline
\end{tabular}


Figure 3 shows that fecal coliforms counts in river water were higher during wet season than dry season at all the sites probably because of inflow of pollution from runoff. Similar observations were made elsewhere [31]. The observed higher counts recorded at Tabata Matumbi and Kigogo Sambusa during wet season was attributed by illegal domestic wastewater discharge into the river by nearby residents from unplanned settlements, which normally open their wastewater chambers during rainy season. Higher level of fecal coliforms at Tabata Matumbi as compared to other sites might be attributed by improper treatment of domestic wastewater from adjacent waste stabilization ponds at Vingunguti.

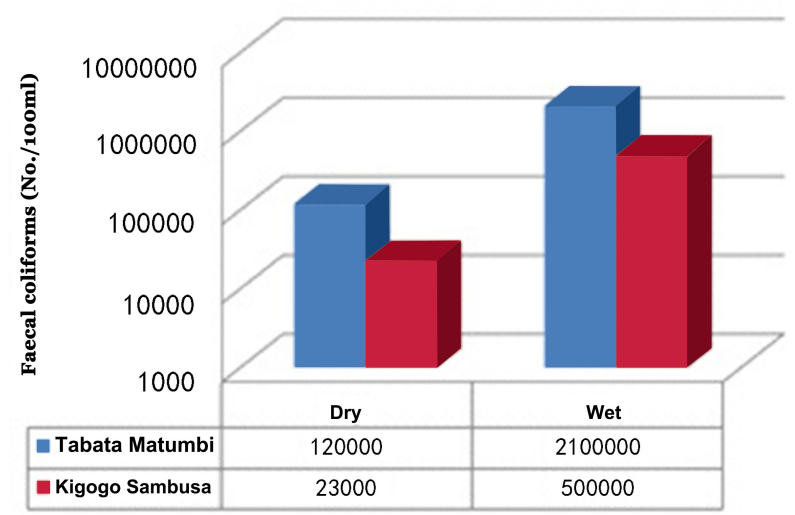

Figure 3. Comparison of fecal coliform counts of irrigation water for the wet and dry

From the farm, all vegetables sample were found contaminated with fecal coliforms, whereby highly contaminated vegetables were, Sweet potato leaves (Ipomea batata) $\left(1.3 \times 10^{6}\right) \mathrm{Cfu} / \mathrm{kg}$, and Chinese cabbage leaves (Brassica chinensis) $3.5 \times 10^{5} \mathrm{Cfu} / \mathrm{kg}$, at Kigogo Sambusa farm, Pumpkin leaves (Curcubita moschata) $\left(7.0 \times 10^{5} \mathrm{Cfu} / \mathrm{kg}\right.$ ) and Kale leaves (Brassica Oleracea) $2.5 \mathrm{x}$ $10^{5} \mathrm{Cfu} / \mathrm{kg}$ at Mabibo Bonde la Mchicha. Contamination can easily occur if untreated manure is applied on soil as fertilizers or when contaminated irrigation water is used
$[32,33]$. The study further reveals that, irrigation water was more polluted as compared to the findings of Tiimub et al. [34]; who reported microbial contamination of less than $10^{4} \mathrm{Cfu} / \mathrm{kg}$.

\section{Microbial Quality of Fresh Vegetables from the Farm}

Table 3 shows that only one type of intestinal parasite, Ascaris lumbricoides, was detected. These nematodes were present in African spinach leaves (Amaranthus spp.) and Chinese cabbage leaves (Brassica chinensis), at Mabibo bonde la Mchicha site. The rest of vegetables were free from contamination of nematode. The presence of Ascaris lumbricoides in African spinach and Chinese cabbage leaves was due to contaminated water used for irrigation. It is worth to mention that Ascaris lumbricoides was found in $83 \%$ of the river water samples collected from the sites. Similar observations were made by several authors who have reported the cause of contamination by helminthes eggs was due to direct contact with contaminated water during irrigation cycle $[35,36]$.

Hajjami et al. (2013) found that the water used for irrigation was as a major route of direct parasitological contamination of fruits and vegetables. Contamination on African spinach leaves which was grown with several others might also be due to location and organic fertilizers applied (manure), Tiimub et al. [34], since different plots on the site are owned by different individuals who get manure from different source. Water used for irrigation was the source for contamination as the water itself had these intestinal parasites. The findings is in agreement with results from study conducted by Hajjami et al. [37] that helminthes eggs loads in vegetables crops are highly dependent on the contamination level of irrigated water. The presence of Ascaris lumbricoides in the vegetables other than other types of nematodes is due to their resistance. Ascaris are very resistant in the environment and they can survive and remain viable in soil and crops for several months and years $[38,39]$.

Table 3. Microbial count and occurrence of fresh vegetables from the farm

\begin{tabular}{|c|c|c|c|}
\hline \multirow{2}{*}{ Parameters } & & \multicolumn{2}{|c|}{ Sampling Station } \\
\hline \multirow{4}{*}{$\begin{array}{c}\text { Fecal coliform } \\
\text { Cfu/kg-wet vegetables }\end{array}$} & Vegetable species & Kigogo Sambusa & Mabibo Bonde la Mchicha \\
\cline { 2 - 4 } & African spinach leaves & $3.0 \times 10^{4}$ & $5.0 \times 10^{4}$ \\
\cline { 2 - 4 } & Pumpkin leaves & $5.0 \times 10^{3}$ & $7.0 \times 10^{5}$ \\
\cline { 2 - 4 } & Chinese cabbage leaves & $3.5 \times 10^{5}$ & $4.0 \times 10^{4}$ \\
\hline \multirow{4}{*}{ Helminthes Eggs } & Sweet potato leaves & $1.3 \times 10^{6}$ & Not measured \\
\hline & Kale leaves & Not measured & Ascaris lumbricoides \\
\cline { 2 - 4 } & African spinach leaves & Not Detected & Not Detected \\
\cline { 2 - 4 } & Pumpkin leaves & Not Detected & Ascaris lumbricoides \\
\cline { 2 - 4 } & Chinese cabbage leaves & Not Detected & Not Detected \\
\cline { 2 - 4 } & Sweet potato leaves & Not Detected & Not measured \\
\hline
\end{tabular}

$\mathrm{Cfu} / \mathrm{kg}=$ colony forming unity per kilogram 
Table 4. Microbial counts and occurrence of vegetables from the markets

\begin{tabular}{|c|c|c|c|c|}
\hline \multirow{2}{*}{ Parameters } & \multirow[b]{2}{*}{ Vegetable species } & \multicolumn{3}{|c|}{ Sampling points } \\
\hline & & Kigogo Market & Mabibo Market & Super Market \\
\hline \multirow{5}{*}{$\begin{array}{l}\text { Fecal coliform } \\
\text { Cfu/kg-wet }\end{array}$} & African spinach leaves & $5.9 \times 10^{8}$ & $7.5 \times 10^{4}$ & $1.9 \times 10^{4}$ \\
\hline & Pumpkin leaves & $6.9 \times 10^{8}$ & $2.5 \times 10^{8}$ & - \\
\hline & Chinese cabbage leaves & $5.7 \times 10^{8}$ & $6.5 \times 10^{8}$ & $1.7 \times 10^{4}$ \\
\hline & Sweet potato leaves & $5.0 \times 10^{8}$ & $5.0 \times 10^{4}$ & $2.7 \times 10^{6}$ \\
\hline & Kale leaves & - & - & $1.1 \times 10^{4}$ \\
\hline \multirow{5}{*}{ Helminthes Eggs } & African spinach leaves & Ascaris lumbricoides & Ascaris lumbricoides & Ascaris lumbricoides \\
\hline & Pumpkin leaves & Ascaris lumbricoides & Ascaris lumbricoides & Not Detected \\
\hline & Chinese cabbage leaves & Ascaris lumbricoides & Ascaris lumbricoides & Not Detected \\
\hline & Sweet potato leaves & Ascaris lumbricoides & Ascaris lumbricoides & Not Detected \\
\hline & Kale leaves & - & - & Not Detected \\
\hline
\end{tabular}

Not sampled

$\mathrm{Cfu} / \mathrm{kg}=$ colony forming unity per kilogram

\section{Microbial Quality of Vegetables from the Markets}

Data from the assessment of vegetables sold from the markets, both from local and super market reveal the presence of fecal colifoms, which indicates the potential presence of pathogenic organisms on vegetables (Table 4). The results further reveal that, vegetables from the markets were highly contaminated than those sampled from the farms with an exception of those from super market, which were relatively close to those from the farm $10^{4}$ to $10^{6}$ $\mathrm{Cfu} / \mathrm{kg}$. Contamination values from the farms ranged from $10^{3}$ to $10^{6}$ while from the markets, values ranged from $10^{4}$ to $10^{8} \mathrm{Cfu} / \mathrm{kg}$.

Among the vegetables examined from markets, all the vegetable species at Kigogo market found highly contaminated up to $10^{8} \mathrm{Cfu} / \mathrm{kg}$ followed those at Mabibo markets with fecal coliform count from $10^{4}$ to $10^{8} \mathrm{Cfu} / \mathrm{kg}$. Samples from Supermarket were less contaminated with the highest count of $10^{6} \mathrm{Cfu} / \mathrm{kg}$ on Sweet potato (Ipomea batata) leaves. High contamination levels of vegetables from the local markets were due to various factors, including the dirty surrounding environment with various small pools filled with dirty water and trickling of dirty water on vegetables to keep vegetables fresh. It was also observed that the vegetables displayed for sale are exposed and often touched by unwashed hands of customers and vendors. This was also suggested by Chaturvedi et al. [40], that frequent handling by unhygienic hands is a factor contributing to the high microbial roads. High coliform count on vegetables from super market might be due to poor handling from harvesting, packing and transportation.

For helminthes eggs, Ascaris lumbricoides were detected in all vegetable samples collected from the local markets, while from super market only African spinach leaves was found contaminated. Several studied around the world have reported the presence of intestinal parasites from vegetable sold in market [41]. Contamination of these vegetables from the markets might be due to unhygienic market environment and handling methods of keeping vegetable fresh in the market. Detection of Ascaris lumbricoides in all vegetables was probably because
Ascaris spp is among the most resistant enteric pathogens and it is often used as parasitological indicator and affects about quarter of the world population. Poor sanitation and bad hygienic practice during transportation, packaging and processing by handlers including consumers are among the factors severally reported to influence the quality of vegetables $[42,43]$.

Vegetables picked from the two different farms, show that all vegetable types were contaminated by Escherichia coli. Citrobacter Spp were found on African spinach leaves from both farms, while Pumpkin leaves from Kigogo Sambusa farm, Chinese cabbage leaves and Kale leaves at Mabibo Bonde la Mchicha farm were contaminated by Proteus Spp. Sweet potato leaves from Kigogo Sambusa farm was contaminated by Bacillus Spp. All organisms were Gram negative except for Bacillus spp, which were Gram positive cell and the bacterial growth density was $100 \%$ for all bacteria except Bacillus spp, which grew by $75 \%$.

Table 5 indicates that among the bacteria detected from vegetables, which were picked randomly from different markets, Escherichia Coli were detected from all vegetable types, except for African spinach leaves (Amaranthus spp.) and Sweat potato leaves at Mwenge market and sweat potato leaves at Buguruni market. Citrobacter spp was found on African spinach leaves and Chinese cabbage leaves at Buguruni market and African spinach leaves and Sweet potato leaves at Mwenge market. Proteus spp was found on Pumpkin leaves at Buguruni market while other vegetable species were free from contamination (Table 6).

Krebsiella spp was only found in Sweet potato leaves at Buguruni market while Salmonella spp was in African spinach leaves from Mwenge market. All bacteria were Gram-negative, non-spore forming, rod- shaped bacteria that developed red colonies with a metallic (golden) sheen within 24 hours at $35^{\circ} \mathrm{C}$. All bacteria grew by $100 \%$ except for Citrobacter ssp in sweet potato leaves at Mwenge market and Krebsiella ssp in sweet potato leaves at Buguruni market which grew by $75 \%$ and Salmonella spp in African spinach leaves at Mwenge market which grew by only $50 \%$. 
Table 5. Frequency of occurrence of bacteria on fresh vegetables from the farms

\begin{tabular}{|c|c|c|c|}
\hline \multirow{2}{*}{ Parameters Bacteria } & \multirow[b]{2}{*}{ Vegetable species } & \multicolumn{2}{|c|}{ Sampling points/Farms } \\
\hline & & Kigogo Sambusa & Mabibo Bonde la Mchicha \\
\hline \multirow{5}{*}{ Escherichia coli } & African spinach leaves & $\sqrt{+++}$ & $\sqrt{+++}$ \\
\hline & Pumpkin leaves & $\sqrt{+++}$ & $\sqrt{+++}$ \\
\hline & Chinese cabbage leaves & $\sqrt{+++}$ & $\sqrt{+++}$ \\
\hline & Sweet potato leaves & $\sqrt{+++}$ & $\sqrt{+++}$ \\
\hline & Kale leaves & - & $\sqrt{+++}$ \\
\hline \multirow{4}{*}{ Citrobacter spp } & African spinach leaves & $\sqrt{+++}$ & $\sqrt{+++}$ \\
\hline & Pumpkin leaves & $x$ & $x$ \\
\hline & Chinese cabbage leaves & $x$ & $x$ \\
\hline & Sweet potato leaves & $x$ & $x$ \\
\hline \multirow{5}{*}{ Proteus spp } & African spinach leaves & $x$ & $x$ \\
\hline & Pumpkin leaves & $\sqrt{+++}$ & $x$ \\
\hline & Chinese cabbage leaves & $\times$ & $\sqrt{+++}$ \\
\hline & Sweet potato leaves & $x$ & $\times$ \\
\hline & Kale leaves & - & $\sqrt{+++}$ \\
\hline \multirow{4}{*}{ Krebsiella spp } & African spinach leaves & $x$ & $x$ \\
\hline & Pumpkin leaves & $x$ & $x$ \\
\hline & Chinese cabbage leaves & $x$ & $x$ \\
\hline & Sweet potato leaves & $x$ & $x$ \\
\hline \multirow{4}{*}{ Salmonella spp } & African spinach leaves & $x$ & $x$ \\
\hline & Pumpkin leaves & $x$ & $x$ \\
\hline & Chinese cabbage leaves & $x$ & $x$ \\
\hline & Sweet potato leaves & $x$ & $x$ \\
\hline \multirow{4}{*}{ Bacillus spp } & African spinach leaves & $x$ & $x$ \\
\hline & Pumpkin leaves & $x$ & $x$ \\
\hline & Chinese cabbage leaves & $x$ & $x$ \\
\hline & Sweet potato leaves & $\sqrt{++}$ & $x$ \\
\hline
\end{tabular}

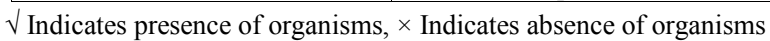

+ Density of organism ( $+50 \%$ growth, $++75 \%$ growth, $+++100 \%$ growth)

Not sampled

Table 6. Frequency of occurrence of bacteria on fresh vegetables from different markets

\begin{tabular}{|c|c|c|c|c|c|}
\hline \multirow{2}{*}{$\begin{array}{c}\text { Parameters } \\
\text { Bacteria }\end{array}$} & \multirow{2}{*}{ Vegetable species } & \multicolumn{4}{|c|}{ Sampling Station/ Markets } \\
\hline & & Kariakoo & Buguruni & Kigogo & Mwenge \\
\hline \multirow{4}{*}{ Escherichia coli } & African spinach leaves & $\sqrt{+++}$ & $\sqrt{+++}$ & $\sqrt{+++}$ & $x$ \\
\hline & Pumpkin leaves & $\sqrt{+++}$ & $\sqrt{+++}$ & $\sqrt{+++}$ & $\sqrt{+++}$ \\
\hline & Chinese cabbage leaves & $\sqrt{+++}$ & $\sqrt{+++}$ & $\sqrt{+++}$ & $\sqrt{+++}$ \\
\hline & Sweet potato leaves & $\sqrt{+++}$ & $x$ & $\sqrt{+++}$ & $x$ \\
\hline \multirow{4}{*}{ Citrobacter spp } & African spinach leaves & $x$ & $\sqrt{+++}$ & $x$ & $\sqrt{+++}$ \\
\hline & Pumpkin leaves & $x$ & $x$ & $x$ & $x$ \\
\hline & Chinese cabbage leaves & $x$ & $\sqrt{+++}$ & $x$ & $x$ \\
\hline & Sweet potato leaves & $x$ & $x$ & $x$ & $\sqrt{++}$ \\
\hline \multirow{4}{*}{ Proteus spp } & African spinach leaves & $x$ & $\times$ & $\times$ & $\times$ \\
\hline & Pumpkin leaves & $x$ & $\sqrt{+++}$ & $\times$ & $x$ \\
\hline & Chinese cabbage leaves & $x$ & $x$ & $\times$ & $x$ \\
\hline & Sweet potato leaves & $x$ & $x$ & $x$ & $x$ \\
\hline \multirow{4}{*}{ Krebsiella spp } & African spinach leaves & $x$ & $x$ & $\times$ & $x$ \\
\hline & Pumpkin leaves & $x$ & $x$ & $x$ & $x$ \\
\hline & Chinese cabbage leaves & $x$ & $x$ & $x$ & $x$ \\
\hline & Sweet potato leaves & $x$ & $\sqrt{++}$ & $\times$ & $x$ \\
\hline \multirow{4}{*}{ Salmonella spp } & African spinach leaves & $x$ & $x$ & $x$ & $\sqrt{+}$ \\
\hline & Pumpkin leaves & $x$ & $x$ & $x$ & $x$ \\
\hline & Chinese cabbage leaves & $\times$ & $x$ & $x$ & $x$ \\
\hline & Sweet potato leaves & $x$ & $x$ & $x$ & $x$ \\
\hline \multirow{4}{*}{ Bacillus spp } & African spinach leaves & $x$ & $x$ & $x$ & $x$ \\
\hline & Pumpkin leaves & $x$ & $x$ & $x$ & $x$ \\
\hline & Chinese cabbage leaves & $x$ & $x$ & $\times$ & $x$ \\
\hline & Sweet potato leaves & $x$ & $x$ & $x$ & $\times$ \\
\hline
\end{tabular}

$\sqrt{ }$ Indicates presence of organisms, $\times$ Indicates absence of organisms

+ Density of organism ( $+50 \%$ growth, $++75 \%$ growth, $+++100 \%)$ 
Figure 4 shows that among the organisms present on vegetables, counting the percentage variations indicates that contamination by Escherichia coli was about $61 \%$ where, Citrobacter spp 18\%, Proteus spp 12\%, Klebsiella spp 3\%, Salmonella spp 3\% and Bacillus spp 3\%. High percentage of $E$. coli might be due to irrigating vegetables using water containing untreated sewage or manure, and contaminated wash water [44]. E. coli O157:H7 is known to be very resistant unless is destroyed by thorough cooking or pasteurization. It can survive for extended periods of time in water and soil, under frozen and refrigerated temperatures, and in dry conditions as well. It also can adapt to acidic conditions [45] and they are widely distributed in air, dusts and soils [46]. Some researchers have shown that the use of contaminated water is the source of pathogens from harvested produce [47]. However, leafy vegetables have the greatest risk of infection from manure application to soil. At the farm vegetable contamination can be due to contact with cattle, sheep, birds, insects and squirrels feces.

At the market, contaminated surfaces, including human hands and places like tables where vegetables are placed are major source of bacterial contamination that often come in contact with produce and represent potential points of cross-contamination throughout packing, processing, and preparing produce for consumption $[42,44]$. Though many pathogens can cause health problems with fresh produce, Escherichia coli is of special concern since very few of their cells are enough to cause illness, and the illness can progress quickly to cause severe consequences in susceptible people, like children and the elderly. One group of Escherichia coli, which includes O157:H7, produces a powerful toxin that damages the lining of the small intestine, which can cause bloody diarrhea. One can develop an Escherichia coli infection when this strain of bacteria is ingested [48].

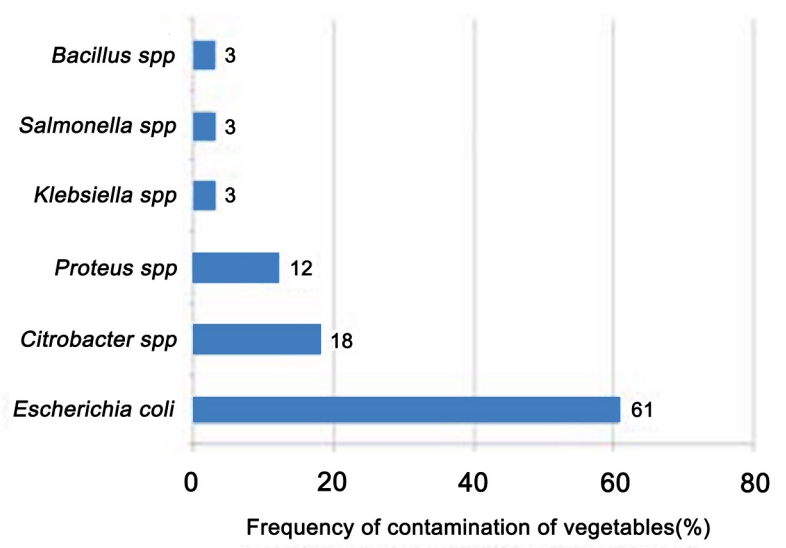

Figure 4. Variations of various microorganisms on fresh vegetables

Figure 5 shows variation of contamination of different types of vegetables whereby African spinach leaves (Amaranthus ssp.) was found to be highly contaminated by $29 \%$, followed by pumpkin leaves (curcubita moschata) by 24\% and Chinese cabbage leaves (Brassica chinensis), 23\% and Kale leaves (Brassica Oleracea) 3\%. High incidence of microorganisms in African spinach leaves might be due to general morphology of its leaves that expose much of its surface area to the contaminated water [20].

\section{Vegetable Species}

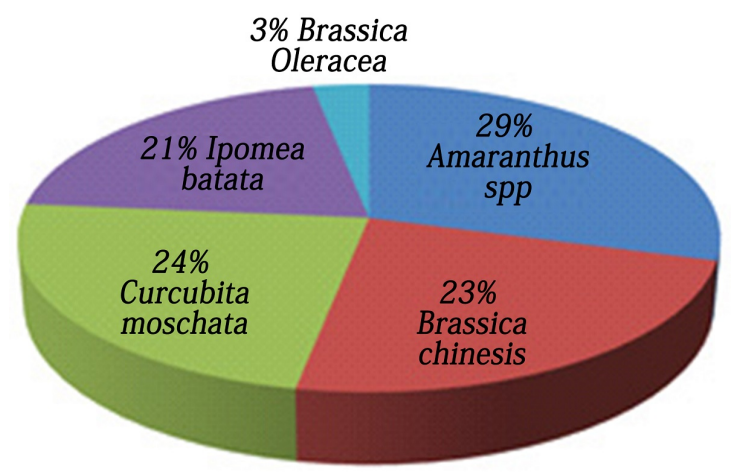

Figure 5. Percentage variation of vegetables types' contaminated

\section{Conclusions}

Based on the findings of the study, the following conclusions can be drawn.

- Water from Msimbazi River is not suitable for irrigation because it contains some pathogenic bacteria, Helminthes eggs and high concentration of salts. Pollution of the river is increasing downstream and is greatly contributed by land use. The quality of the river is affected by seasonal variations whereby there is much pollution during wet season than dry season.

- Vegetables from all the markets including super market are highly contaminated with fecal coliforms of up to $10^{8} \mathrm{Cfu} / \mathrm{kg}$-wet and helminthes eggs especially Ascaris lumbricoides. Vegetables that are sold at the markets are highly contaminated as compared to those at the farms. High number of fecal coliforms in markets is due to poor handling of these vegetable mostly by contaminated hands and sprinkling of vegetables with polluted water to keep vegetables moist.

- Fresh vegetables may potentially cause illnesses since they were all found contaminated with disease causing organisms such as Escherichia coli, Citrobacter ssp, Proteus ssp, Klebsiella ssp, Salmonella spp and Basillus spp.

\section{REFERENCES}

[1] Jørgensen B., Graymore M., O'Toole K., 2009. Household water use behavior: An integrated model. Journal of Environmental Management, 91: 227-236. 
[2] Schmidt S., 2011. Urban Agriculture in Dar es Salaam, Tanzania; Food policy for Developing countries: The Role of Government in Global food system Case Studies. 10pp.

[3] Merker I., 2004. Wastewater use for irrigation in agriculture in India (Internship South India). Lancer No. 9.

[4] Marwa J., 2011. Assessment of potential health risks of waste stabilization ponds effluents and sludge use for irrigating vegetables: A case of Lemara WSP, Arusha Municipality Tanzania, Master's Thesis, Department of Water Resources Engineering, University of Dar es Salaam.

[5] Aydinalp C., Marinova S., 2012. Concentration of $\mathrm{Cu}$ and $\mathrm{Zn}$ in Some Fruits and Vegetables Grown in North Western Turkey. Bulgarian Journal of Agricultural Science, 18(5): 749-751.

[6] Ensink J.H., Mahmood T., Dalsgaard A., 2007. Wastewater-irrigated vegetables: market handling versus irrigation water quality. Tropical Medicine and International Health, 12(Suppl 2): 2-7.

[7] Kayombo M.C., 2015. Assessment of chemical and microbial quality of vegetables irrigated with polluted waters in Dar es Salaam City, Masters of Sanitation Management, Department of Water Resources Engineering, University of Dar es Salaam.

[8] Huibers F.P., van Lier J.B., 2005. Use of Wastewater in Agriculture: The water chain approach. Irrigation and Drainage, 54: S3-S9.

[9] Drechsel P., Graefe S., Sonou M., Cofie O.O., 2006. Informal Irrigation in urban West Africa: an overview. Colombo, Sri Lanka. International Water Management Institute. IWMI Research Report, 102: 1-34.

[10] Obi C.L., Potgieter N., Bessong P.O., Matsaung G., 2002. Assessment of the microbial quality of river water sources in rural Venda communities in South Africa. Water SA, 28(3): 287-292.

[11] Raicevic V., Kljujev I., Petrovic J., 2010. Microbial Contamination of Irrigation water, Fruits and vegetables. Faculty of Agriculture, University of Belgrade, Serbia.

[12] Beuchat L.R., 2002. Ecological factors influencing survival and growth of human pathogens on raw fruits and vegetables. Microbes and Infection, 4: 413-423.

[13] Guo, X., Chen, J., Brackett, R.E., Beuchat, L.R., 2001. Survival of Salmonellae on and in tomato plants from the time of inoculation at flowering and early stages of fruit development through fruit ripening. Applied and Environmental Microbiology, 67(10): 4760-4764.

[14] Breuer, T., Benkel, D.H., Shapiro, R.L., Hall, W.N., Winnett, M.M., Linn, M.J., Timothy, J.N., Barrett, J., Dietrich, S., Downes, F.P., Toney, D.M., Pearson, J.L., Rolka, H., Slutsker. L., Griffin, P.M., 2001. A multi-state outbreak of Escherichia coli O157:H7 infections linked to alfalfa sprouts grown from contaminated seeds. Emerging Infectious Diseases, 7(6): 977-982.

[15] Evans R.M., Ribero C.D., Salmon L.R., 2003. Hazards of Healthy Living: Bottled Water and Salad Vegetables as Risk Factors for Campylobacter Infection, Emerg Infect Dis, 9: $1219-1225$.

[16] Ibenyassine K., Mhand R.A., Kamoko Y., Anajjar B.,
Chouibani M.M., Ennaji M, 2007. Bacterial pathogens recovered from vegetables irrigated by wastewater in Morocco. Journal of Environmental Health, 69(10): 47-51.

[17] Kihila J., Mtei M., Njau K., 2014. Wastewater treatment for reuse in Urban Agriculture: The case of Moshi Municipality, Tanzania. Physics and Chemistry of the Earth, Parts A/B/C, (72-75): 104-110.

[18] Mero R., 2011. Assessment of water quality and special distribution of major pollutants in Ngerengere river catchment, Tanzania, Master of Science in Integrated Water Resources Management, Department of Civil Engineering, University of Zimbabwe.

[19] Mwegoha W.J.S., Leonard L.S., Kihampa C., 2012. Heavy metal pollution and Urban Agriculture in Msimbazi river valley: Health risks and public awareness. IJPAES, 2(2): 107-118.

[20] Amoah P., Drechsel P., Abaidoo R.C., 2005. Irrigated urban vegetable production in Ghana: sources of pathogen contamination and health risk elimination. Irrigation and Drainage, 54: S49-S61.

[21] Yeasmin N.J., Ashraful I. and Shawkat A. (2013). Transfer of metals from soil to vegetables and possible health risk. Springer Plus, 2: 385.

[22] Dongas S., 2000. Vegetable production on open spaces in Dar es Salaam - Spatial changes from 1992-1999; Published by city Farmer, Canada's office of Urban Agriculture.

[23] United Republic of Tanzania Population Censors report, 2013. Population distribution by Administrative Units; The 2012 Population and Housing Census (PHC).

[24] American Public Health Association (APHA), American Water Works Association (AWWA), Water Environment Federation (WEF) (2012). Standard Methods for the Examination of Water and Wastewater, $22^{\text {nd }}$ edition, Washington, DC.

[25] Ayres R.M., Mara D.D., 1996. Analysis of Wastewater for Use in Agriculture - A Laboratory Manual of Parasitological and Bacteriological Techniques. World Health Organization, Geneva, Switzerland.

[26] de Silva NR, Brooker S, Hotez PJ, Montresor A, Engels D, Savioli L., 2003. Soil-transmitted helminth infections: updating the global picture. Trends in Parasitology, 19(12):547-551.

[27] Kanneganti K., Makker J.S., Remy P., 2013. Ascaris lumbricoides: To Expect the Unexpected during a Routine Colonoscopy. Case Reports in Medicine, Hindawi Publishing Corporation, Article ID 579464, http://dx.doi.or g/10.1155/2013/579464.

[28] WHO, 2006. WHO guidelines for the safe use of wastewater, excreta and greywater: Wastewater use in agriculture. Volume II, World Health Organization, France, 22p.

[29] Cotruvo J.A., Dufour A., Rees G., Bartram J., Carr R., Cliver D.O., Craun G.F., Fayer R., Gannon V.P.J. (Ed.), 2004. Waterborne Zoonoses; Identification, Causes and Control. Emerging issues in water and infectious diseases series, IWA publishing, World Health Organization.

[30] Abakpa G.O., Umoh V.J., Ameh J.B., Yakubu S.E., 2013. Microbial quality of irrigation water and irrigated vegetables 
in Kano State, Nigeria. Department of Microbiology, Ahmadu Bello University Zaria, Kaduna State, Nigeria. International Food Research Journal, 20(5): 2933-2938.

[31] Kistemann T., ClaBen T., Koch C., Dagendorf F., Fischeder R., Gebel J., 2002. Microbial load of drinking water reservoir tributaries during extreme rainfall and runoff. Applied and Environmental Microbiology, 68: 2188-2187.

[32] Amponsah-Doku F., Obiri-Danso K., Abaidoo R.C., Andoh, L.A., Drechsel P., Kondrasen F., 2010. Bacterial contamination of lettuce and associated risk factors at production sites, markets and street food restaurants in urban and peri- urban Kumasi, Ghana. Scientific Research and Essays, 5(2): 217-223.

[33] Mensah P., Yeboah-Manu D., Owusu-Darko K., Ablordey A., 2002. Street food in Accra, Ghana: How safe are they? Bulletin WHO, 80: 546-554.

[34] Tiimub B.M., Kuffour R.A., Kuarteng A.S., 2012. Bacterial contamination levels of Lettuce irrigated with waste water in the Kumasi Metropolis. Journal of Biology, Agriculture and Healthcare, 2(10): 116-127.

[35] Firadi R., 1996. Épuration et réutilisation des eaux usées de la ville de Ouarzazate en agriculture: Devenir des oeufs d'helminthes et étude de leur viabilité dans les eaux usées et les boues. Thèse de 3ème cycle, Faculté des sciences, Marrakech, Morroco. (In French)

[36] Dssouli K., 1997. Réutilisation des eaux usées de la ville d'Oujda en agriculture: étude de l'aspect parasitologique (helminthes parasites). Thèse 3ème cycle. Faculté des Sciences, Oujda. (In French)

[37] Hajjami K., Ennaji M., Amdiouni H., Fouad S., Cohen N., 2013. Parasitic Contamination on Fresh Vegetable Consumed in Casablanca City (Morocco) and Risk for consumer. International Journal of Science and Technology, 2(7): 543-549.

[38] Jiang X., Morgan J. and Doyle M.P. (2002). Fate of Escherichia coli O157:H7 in manure- amended soil. Appl. Environ. Microbiol., 68: 2605-2609.

[39] Ogden I.D., Hepbun N.F., MacRae M., Strachan N.J., Fenlon D., Rusbridge S.M., Pennington T.H., 2002.
Long-term survival of Escherichia coli $\mathrm{O} 157$ on pasture following an outbreak associated with sheep at a scout camp. Lett. Appl. Microbiol., 34(2): 100-104.

[40] Chaturvedi M., Kumar V., Singh D., Kumar S., 2013. Assessment of microbial load of some common vegetables among two different socioeconomic groups; Dehradun, Uttarakhand, India. International Food Research Journal, 20(5): 2927-2931.

[41] Idrissa S., Belghyti D., El Kharrim K. and Yoro C., 2010. Parasitic Contamination of the Mint and Turnip Irrigated By Untreated Wastewater in Sidi Yahia Gharb (Morocco), BALWOIS 2010, Ohrid, Republic of Macedonia, 25- 29 May.

[42] Beuchat L.R., Ryu J., 1997. Produce Handling and Processing Practices. Emerging Infectious Diseases, 3(4): 459-465.

[43] Kang J.S., Park W.P., Lee D.S., 2000. Quality of enoki mushrooms as affected by packaging conditions. Journal of Science of Food and Agriculture, 81: 109-114.

[44] Davis J.G., Kendall P., 2014. Preventing E. Coli from Garden to plate. Colorado University Extension. A division of the office of engagement.

[45] Chang J., Fang T., 2007. Survival of Escherichia coli O157:H7 and Salmonella enterica serovars Typhimurium in iceberg lettuce and the antimicrobial effect of rice vinegar against E. coli O157:H7. Food Microbiology, 24: 745-751.

[46] Oladele A.S., Olakunle O., 2011 Microorganisms Associated with the Deterioration of Fresh Leafy Indian Spinach in Storage. J. Plant Pathol Microbiol., 2(3): 1-3. doi:10.4172/2157-7471.1000110.

[47] Gast K.L., 2000. Minimizing Microbial Food Safety Hazards for Fresh Fruits and Vegetables, Agricultural water, Kansas State University, Agricultural experiment station and Cooperative Extension Service.

[48] Lynch L.F., Tauxe R.V., Hedberg C.W., 2009. The growing burden of food-borne outbreaks due to contaminated fresh produce: risks and opportunities. Epidemiol Infect., 137: 307-15. 